invaginable tube which passes through the nerve ring ventral to the gut. The tube, together with its accompanying muscular pouch, is reminiscent of the copulatory apparatus of Omalogyra ${ }^{4}$, which, however, is contained within the hermaphrodite duct and is not an independent structure. The eggs of Odostomia spp. are laid on their feeding grounds-on the shells of lamellibranchs or among the tubes of polychætes. A number of eggs are embedded in a copious supply of jelly ${ }^{3}$ which binds them together and to the substratum, and which is produced by the hypertrophy of the upper part of the pallial oviduct during the female phase of these protandrous hermaphrodites.

The structure of the nervous system, gut and reproductive system may be shown to be consistent with the classification of the Pyramidellidæ as prosobranchs rather than opisthobranchs.

V. Fretter

A. Graham

Department of Zoology,

Birkbeck College,

London, E.C.4.

Oct. 29.

${ }^{1}$ Pelseneer, Bull. Sci. France Belgique, 48, 1 (1914).

"Ankel, "Die Tierwelt der Nord- und Ostsee", IXb (Akademische Verlagsgesellschaft, Leipzig, 1936).

${ }^{3}$ Thorson, Medd. Komm. Havundersøg., Kbh., Plankton, 4 (1946).

4 Fretter, J. Mar. Biol. Assoc., 27, 597 (1948).

\section{Cotton Crop Yield in Relation to Applica- tion of Fertilizers}

IT is unfortunate that efforts to study the effect of various fertilizers on the cotton yield in Egypt have led to contradictory results. Thus Hughes ${ }^{1}$, Prescott ${ }^{2}$, and Khalil and co-workers ${ }^{3}$ have reported that manuring has very little or no effect on the yield of cotton crop, while Mahmoud and Crowther ${ }^{4,5,6}$ have shown that cotton produces better yield in response to nitrogen and phosphate applications, potash addition being without effect.

Several investigators ${ }^{7,8,9}$ have found a correlation between the mineral composition of plant leaves, crop yield and fertilizer applications. We have carried out an experiment in which we have used foliar analysis of cotton (variety Menoufy) as an index to the nutrient conditions and crop yield of the plants. The soil plots that have been used in the present investigation are loamy in texture, situated in the farm of the Faculty of Agriculture, Fouad I University, at Giza, and have been under five controlled treatments since 1932. Each plot has seven replicates $(9.20 \times 8.20 \mathrm{~m}$.) distributed according to the Latin square method.

The results seem to indicate that addition of any fertilizer gave better yield than that of plants grown in the completely unfertilized plots. It must be remembered, however, that the soil of the untreated plots has been without any fertilizer application since 1932; naturally such soil is rather spent. The plants that have been grown in plots supplied with full manure of phosphorus, potassium and nitrogen gave a higher yield than that obtained from plants given phosphorus and potassium but no nitrogen fertilizer. Non-addition of potassium or phosphorus fertilizer seems to have very little effect on the crop yield. The results have also shown that the Egyptian soil contains relatively large amounts of unavailable phosphorus and potassium, but little nitrogen; hence the need for addition of nitrogen fertilizer alone. We believe that the most suitable nitrogen fertilizer would be ammonium sulphate, because the ammonium-nitrogen will soon be transformed into nitrate by means of nitrifying and nitrating bacteria which are usually abundant in Egyptian soil fit for cultivation. In the meantime the sulphate ion will help to neutralize the alkalinity of the soil (the $p \mathrm{H}$ of the soil being usually about 8.0 ), and in doing so it renders available some of the naturally occurring unavailable phosphorus.

M. EL HINEIDX

F. ALIAM

Faculty of Agriculture,

Fouad University,

Giza. Jan. 22.

${ }^{1}$ Hughes, F., Year Book, Khedivial Agric. Soc. (1909).

${ }^{2}$ Prescott, J. A., Bull. No. 13 Sultanic Agric. Soc. (1924).

"Khalil, F., Gracie, D. S., and Fnan, Ministry of Agric., Egypt, Chemical and Agric. Sec., 152, 1 (1935).

- Mahmoud, A., and Crowther, F., Royal Agric. Soc., Egypt, Teeh. Bull. 22 (1935).

"Mahmoud, A., and Crowther, F., Royal Agric. Soc., Egypt, Tech. Bull. 26 (1936).

Mahmoud, A., and Crowther, F., Royal Agric. Soc., Egypt, Tech. Buli. 30 (1937).

'Beauchamp, C. E., Plant Physiol., 15, 485 (1940).

'Thomas, W., Soil. Sci., 59, 353 (1945).

${ }^{9}$ Lineberry, R. A., and Leland, B., Plant Physiol., 18, 324 (1943).

\section{Intercellular Inclusions in White Mustard Roots Induced by Colchicine Treatment}

DURING the course of an anatomical study of colchicine-induced hypertrophy in white mustard roots, attention has been given to some peculiar intercellular inclusions which are certainly not present in untreated roots. In this study, newly germinated seedlings are immersed in a 0.1 per cent colchicine solution for two hours, thoroughly washed in distilled water and then placed on moist filter paper to grow for a period of three days. At the end of this time, marked hypertrophy, characterized by stunted swollen root tips and an exceedingly dense development of root hairs, is obvious.

As already noted ${ }^{1}$ rows of radially placed intercellular spaces occur at an early stage in the meristem of normal white mustard roots and are thought ${ }^{2}$ to facilitate the more rapid movement of food materials to the surface cells. In hypertrophied root tips they are also conspicuous, but here they frequently contain a granular substance and spherical bodies which are comparable in size, stain reaction and general appearance to nuclei in adjacent cortical cells. Since the walls of the cortical cells forming the spaces are intact, the inclusions might be considered to be of the nature of tyloses or internal 'root hairs' growing from the cortical cells. Such an idea would fit in with the irregular swelling of the epidermal cells, marked increase in cellular volume of the cortex and the abnormal production of root hairs by the root

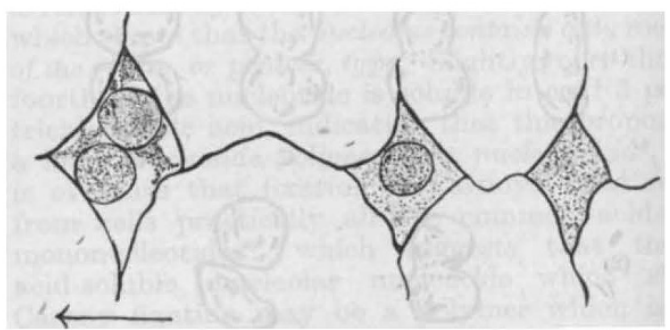

Drawing $\times 1,300$, in cross-sectional view, of one row of radially arranged intercellular spaces in the cortex of a hypertrophied root, showing the intercellular inclusions. The arrow points to the outside of the root 